ISSN 2564-3843

DOI 10.26443/glsars.v1i1.121

\title{
IMPLICATIONS OF URBAN LAW ON URBAN RENEWAL PROJECTS IN THE HISTORICAL
} CENTER OF LIMA*

\begin{abstract}
The Historic Center of Lima currently shows signs of urban deterioration as a result of the processes of exclusion and spatial segregation that have characterized the intense urban growth of the city of Lima. In the face of this urban deterioration, urban renewal processes are an instrument of transformation that acts as surgery for the recovery and reintegration of deteriorated central areas into the functioning of the current city. As a general, urban law regulates urban problems resulting from the transformation of urban lands, including the deterioration of central areas. In particular, actions in traditional central areas have regulations for the protection of cultural heritage. Therefore, the execution of the urban renewal process requires different regulatory instruments to plan and manage the renewal process, which defines its scope. In this sense, the present research has been proposed to address the implementation process of three urban renewal projects in collective housing located in the Historic Center of Lima; "Casa de las Columnas", the "Conjunto de Vivienda La Muralla" and the "Proyecto Piloto Martinete", to identify the effectiveness of the scope of the legal framework of urban renewal, as well as the procedures of intervention in historic centers and monumental areas. Focus on the analysis of the public administration's management, execution, and control activities in the land transformation process of deteriorated traditional urban areas. The article consists of the following parts. First, some conceptual considerations on urban renewal and its relationship with urban law are presented. The next section provides an overview of the state of the regulatory framework for urban renewal in Peru, which is key to contextualize the analysis of the case studies.
\end{abstract}

\footnotetext{
${ }^{*}$ Liz Luisa Isidro Ferrer, Architect; Postgraduate student, Universitat de Barceolna. Contact: lisidroferrer@gmail.com.
} 
The third part presents the study methodology and the limitations of the study. The fourth part presents the case studies and develops the scope of the legal framework of urban renewal in the case studies. Finally, some final reflections and conclusions are presented that establish the important elements that should be considered in the legal framework of urban renewal.

Keywords: urban renewal, urban law, historic center, collective housing

\section{Résumé}

Le centre historique de Lima présente actuellement des signes de détérioration urbaine en raison des processus d'exclusion et de ségrégation spatiale qui ont caractérisé la croissance urbaine de cette ville. Face à cette détérioration, les processus de rénovation de l'espace urbain sont des instruments de transformation permettant de réintégrer les zones centrales détériorées au fonctionnement de la ville actuelle. De façon générale, le droit urbain réglemente les problématiques résultant de la transformation des terrains, y compris la détérioration des zones centrales. Par exemple, des règlements pour la protection du patrimoine culturel sont en place dans ces zones et régule les diverses actions qui peuvent être effectuées en ces lieux. Par conséquent, l'exécution de processus de rénovation de l'espace urbain nécessite différents instruments réglementaires pour planifier et gérer les processus de rénovation. Ces différents instruments définissent la portée des processus de rénovation.

Le présent article examine trois projets de rénovation urbaine dans les logements collectifs situés dans le centre historique de Lima : « Casa de las Columnas », le « Conjunto de Vivienda La Muralla » et le « Proyecto Piloto Martinete ». Cette analyse vise à identifier l'efficacité de la portée du cadre juridique de la rénovation urbaine, ainsi que les procédures d'intervention dans les centres historiques et les différents endroits où se situent les monuments de la ville. L'accent est mis sur les activités de gestion, d'exécution et de contrôle de l'administration publique dans le processus de 
transformation du territoire des zones urbaines traditionnelles détériorées. Pour ce faire, l'article est divisé en plusieurs sections. Tout d'abord, quelques considérations conceptuelles sur la rénovation urbaine et sa relation avec le droit urbain sont présentées. La section suivante donne un aperçu du cadre réglementaire de la rénovation urbaine au Pérou. La troisième section présente la méthodologie et les limites de l'étude. La quatrième section présente les études de cas et développe la portée du cadre juridique de la rénovation urbaine dans les études de cas. Enfin, quelques réflexions et conclusions sont présentées et établissent les éléments importants qui devraient être pris en compte dans le cadre juridique de la rénovation urbaine.

Mots-clés: renovation urbaine, droit urbain, centre historique, logements collectifs

\section{INTRODUCTION}

The Historic Center of Lima, the foundational area of Lima's current urban fabric, houses $97 \%$ of the monumental heritage of the District of Cercado de Lima. ${ }^{1}$ It has $64 \%$ residential monumental architecture, which in 2009 represented $83 \%$ of monuments at risk of collapse. ${ }^{2}$ In 2014, the Remap Lima project 3 , through aerial images, specifically analyzed the area declared a World Heritage Site. The findings exposed several domestic monuments turned into outsourced commercial establishments in a state of collapse or demolition, increasing the number of monuments at risk to $83 \% .{ }^{4}$ At the same time, the Historic Center

\footnotetext{
${ }^{1}$ Silvia De los Rios, 'Centro Histórico de Lima: Patrimonio Vivo y Auténtico en Riesgo' (CIDAP 2009). 2 ibid.

3 'BARRIOS ALTOS: Living with Risk in the Historic Centre - Clima Sin Riesgo' (Clima Sin Riesgo, 4 July 2016) <https://climasinriesgo.net/barrios-altos-living-with-risk-in-the-historic-centre> accessed 10 May 2021.

4 ibid.
} 
of Lima was experiencing a population decline, losing 30,312 residents between 2000 and 2015.5 On average, 2,000 people a year leave the urban area equipped with basic facilities and services. ${ }^{6}$ Today, in addition to the existing factors of urban deterioration, new ones have been added, such as the identity problems generated by globalization, the reduction of social policies, and privatizations that reduce the presence of the State. 7

As a general rule, in historical centers with a concentration of monuments or protected buildings and environments of heritage value, strict ordinances are required for ensuring historic preservation. ${ }^{8}$ These limit the development options of building owners and residents without the State offering economic or technical incentives for their proper maintenance. 9 Another form of regulation that generates urban deterioration is the rent control policy, especially when the measure is partial or isolated from other housing policies. ${ }^{10}$ As a result, if rental contracts are not modified, landlords refrain from improving the properties. This ends up hurting tenants by not expanding or improving the supply of housing. ${ }^{11}$ Hence, these measures contribute to long-term precariousness and informality.

5 Silvia De los Rios, 'Sigue el reto de la revitalización del Centro Histórico de Lima. Centro vivo y auténtico' (CIDAP 2015) 4.

6 ibid.

7 P Biehl and C Prescott, 'The Future of Heritage in a Globalized World' in P Biehl and C Prescott (eds), Heritage in the Context of Globalization Europe and the Americas (Springer 2013), 117-120.

8 G Wijesuriya, J Thompson and C Young, Managing Cultural World Heritage (UNESCO World Heritage Centre 2013).

9 CEPROMUR, CEPROMUR y los Procesos de Renovación Urbana, Una reflexión desde la práctica (CEPROMUR 2010) 30.

10 David Kiefer, 'Housing Deterioration, Housing Codes and Rent Control' (1980) 17 US 53, 61-62 <http://dx.doi.org/10.1080/00420988020080061>.

${ }^{11}$ E Rojas, E Rodríguez Villaescusa and EA Wegelin, Volver Al Centro: La Recuperación De Áreas Urbanas Centrales (Banco Interamericano de Desarrollo 2004) 12. 
Also, they negatively impact housing preservation and discourage investment in rental housing.

Under such conditions, urban renewal becomes an alternative for dealing with urban deterioration. Urban renewal proposes to reconcile the physical, social, and economic fabric of the deteriorated area with the needs of the present and adjust to changing urban demands. ${ }^{12}$ According to Rojas, this complex process requires the concerted action of public and private actors around a comprehensive urban transformation and long-term development project. The author adds that, due to the institutional and financial challenges associated with the urban renewal process, public leadership and the active participation of all stakeholders are vital. ${ }^{13}$

As far as Peru is concerned, urban renewal processes for collective housing purposes have been a conglomerate of scattered and disconnected programs. It has been basically due to a lack of political decisions, insufficient management capacity, and inadequate mechanisms to facilitate effective citizen participation. ${ }^{14}$ Currently, the legal framework established for urban renewal has validated and guided some parts of the process. However, there are still gaps and inadequacies in the regulations that have not facilitated finishing many of the projects initiated. ${ }^{15}$ Moreover, the renewal of traditional centers leads what to face one of the most challenging legal issues in the country: land tenure regularization.

${ }^{12}$ AM Broudehoux, 'Neighborhood Regeneration in Beijing: An Overview of Projects Implemented in the Inner City since 1990' (Unpublished master's thesis, McGill University 1994) 4-5.

13 Rojas (n 11) 23.

14 CEPROMUR, 'Cartilla Metodológica: Renovación Urbana, Liderazgo Municipal' (CEPROMUR 2011) 12.

15 CEPROMUR, CEPROMUR y los Procesos de Renovación Urbana, Una reflexión desde la práctica (n 9) 20. 
Properties often lack physical-legal regularization due to economic factors, lack of documentation, or family conflicts. ${ }^{16}$

In addition to these shortcomings, urban renewal initiatives have not had adequate financial resources for implementation. Either because the public financing system for housing policies provides no support to urban renewal programs, or because the economic precariousness of those living in deteriorated areas limits their access to credit, or because there are no incentives to attract private investment. ${ }^{17}$ Thus, the few rehabilitation or restoration experiences in Lima have been achieved through the contribution of international agencies, reporting a high level of subsidized financing. Therefore, the replication of projects remains a permanent challenge.

In general terms, urban law is the set of rules and principles that regulate public and private actions in the urban environment. It aims to provide adequate legal provisions for the management and sustainable use of urban land. ${ }^{18}$ In practice, however, cities are often governed by laws that do not conform to the prevailing urban reality. Another common problem is that public administrations are not always able to enforce laws and regulations. ${ }^{19}$ Consequently, citizens often have to bypass formal avenues to acquire land, property, goods, and services due to the rigidity and complexity of laws and regulations. As a result, parallel systems thrive as urban legal informality becomes the norm, resulting in blighted urban

\footnotetext{
16 ibid 32.

17 ibid 33 .

${ }^{18}$ Ivan Ortiz, Introducción al Derecho Urbanístico (Fondo Editorial Pontificia Universidad Católica del Perú 2017) 31-32.

19 'What is Urban Law?' (Urban Policy Platform, 18 December 2020) $<$ https://urbanpolicyplatform.org/legislation/> accessed o1 July 2021.
} 
environments. ${ }^{20}$ This means that urban law faces multiple urban problems associated with land transformation, such as the deterioration of urban areas. ${ }^{21}$ Against this backdrop, urban renewal, i.e., the process of improving deteriorated urban spaces, is regulated and limited by the regulatory and administrative framework established by the State as a whole. ${ }^{22}$ Despite its importance, Gonzales points out that urban law in Peru is an emerging discipline whose general principles and jurisprudence are still developing. ${ }^{23}$

This research is composed of the following parts. First, an overview of the topic of urban renewal associated with urban law is provided in the study. The next part is concerned with analyzing the legal provisions regulating urban renewal in Peru, which provides a context for understanding the case studies analyzed. The third part of the paper presents three case studies of urban renewal projects in collective housing; The Casa de las Columnas, the Housing Complex La Muralla, and Pilot Project Martinete. Finally, the research summarizes some key recommendations and conclusions on urban renewal strategies in deteriorated historic cities.

\section{PART 1. CONCEPTUALIZATION OF URBAN RENEWAL AND ITS LEGAL FRAMEWORK}

Urban renewal, conceived as an instrument for the transformation and recovery of deteriorated urban structures, has been applied in underutilized and abandoned urban areas in cities around the world, from postwar European towns to today's urban centers. ${ }^{24}$ Based

\footnotetext{
20 ibid.

${ }^{21}$ Guillermo Cervera, La Renovación Urbana y su Régimen Jurídico (Reus 2013).

22 ibid 8-9.

23 Gunther Gonzales, Derecho Urbanístico (Legales Ediciones 2014) 149.

24 Broudehoux (n 12) 10.
} 
on these interventions, a series of research studies are beginning to be developed based on the experiences and results of urban renewal processes and the possibilities of their application in different urban centers.

First of all, it is necessary to define urban renewal, since terms such as urban revitalization, urban regeneration, urban recovery, urban renewal, and urban rehabilitation are used with certain synonymy and laxity in the urban planning field.25 By taking into account the theories of Temes and Grebler this research uses both terms as definitions of urban renewal in a complementary manner. According to Temes, urban renewal refers to the process of planned and sustainable improvement carried out by the administration. This process renews the economic, social, functional, and physical characteristics of an urban area in a state of deterioration. To this end, new services and infrastructures will be provided to enable optimal use according to the needs of the current [and future] society. ${ }^{26}$

In the view of Grebler ${ }^{27}$, urban renewal is the deliberate transformation of existing urban areas by a large-scale plan to accommodate the present and future needs of urban society. The process involves the comprehensive re-planning and redevelopment of land, or the conservation and rehabilitation of areas considered ruined that should be preserved for their historic location and cultural value, all within a broader urban development plan. In this sense, Grebler points out that national attention toward urban issues extends far beyond mere public housing plans in having a national program supported by financial support and other assistance. In contrast to the simple replacement of individual parts or structures,

\footnotetext{
25 Rojas (n 11) 17.

${ }^{26}$ Rafael Temes, 'El Tapiz De Penélope. Transformaciones Residenciales Sobre Tejidos Sin Valor Patrimonial.' (Unpublished doctoral dissertation, Universidad Politécnica de Valencia 2007).

${ }^{27}$ Leo Grebler, Urban Renewal in European Countries (University of Pennsylvania Press 1964).
} 
building by building, urban renewal contains a great deal of government effort, national financial support, planning, and large-scale projects.

Equally important is the literature produced based on case studies. In this line, Rojas studies the characteristics of the problem of urban renewal from the analysis of the factors that give rise to it and the reasons why it constitutes a field of interest for public policy ${ }^{28} \mathrm{He}$ also delves into the economic logic of the investment of public funds, and different financing and execution options for urban renewal programs. In addition, in the local context in Peru, CEPROMUR proposes the systematization of the levels of institutional intervention and the key axes of intervention in urban renewal, such as physical characteristics, social aspects, legal support, economic support, and political advocacy capacity.29 It also proposes methodologies and strategies for undertaking urban renewal processes. $3^{0}$

Regarding the relationship between the legal scope and urban renewal, Rojas states that the characteristics adopted by the urban renewal process and the instruments used to carry it out depend, among other things, on the legislative and urban planning tradition of the country in which it takes place. ${ }^{31}$ As a result, it is crucial to understand the relationship between the different levels of government involved and their specific responsibilities. Another significant component of urban renewal policies is the regulations that allow for

\footnotetext{
${ }^{28}$ Rojas (n 11) 17-40.

29 CEPROMUR, CEPROMUR y los Procesos de Renovación Urbana, Una reflexión desde la práctica (n 9) 27-31.

30 CEPROMUR, 'Cartilla Metodológica: Renovación Urbana, Liderazgo Municipal' (n 14) 26-41.

${ }^{31}$ Rojas (n 11) 17-18.
} 
public-private partnerships. In addition, in terms of upgrading deteriorated areas, land ownership, and land management strategies are also relevant legal issues..$^{2}$

Despite the relevance of the legal sphere, Cervera states that urban renewal has not been the object of attention in urban planning legislation. 33 The process is neither conceived of as a global phenomenon nor as one that could be subdivided into phases. Specifically, he points out that when urban planning legislation is analyzed in search of provisions referring to the demolition of buildings, a prerequisite for urban renewal, this urban planning activity is not valued in terms of its content. 34 Rather, it is treated as the declaration or not of the ruinous state of a building, or as a disciplinary measure for the reestablishment of the infringed urban planning ordinance. Consequently, the author states that urban renewal is not a recognized and relevant legal institution in terms of urban law. 35

Notwithstanding the above, the existing legal system contains sufficient legal elements to establish a legal regime for urban renewal. In this regard, CEPROMUR ${ }^{36}$ compiles the legal framework established for urban renewal in Peru since 1970. This document shows that the norms were issued by different public institutions and were modified according to the short-term political visions of the governments in power. This is because the results of urban transformation are evident in the long term and do not produce immediate political gains. ${ }^{37}$ Consequently, the absence of a specific legal framework has

\footnotetext{
32 ibid.

33 Cervera (n 21) 62.

34 Cervera (n 21) 63.

35 ibid.

${ }^{6}$ CEPROMUR, 'Cartilla Metodológica: Renovación Urbana, Liderazgo Municipal' (n 14) 26-31.

37 CEPROMUR, 'Cartilla Metodológica: Renovación Urbana, Liderazgo Municipal' (n 14) 26-31.
} 
given rise to legal vacuums that are filled with the eagerness to find immediate alternatives and with norms that do not make comprehensive solutions possible.

In this light, it is pertinent to note that the Peruvian State has intricate urban legislation, which means that the principle of certainty is put to the test every day. Because of this, it is not clear which rule is in force or which has preferential application over the others. ${ }^{38}$ This situation has negative consequences because there is no General Urban Land Law in the country, which contains the general principles and rules governing the exercise of competencies of territorial planning, use, and management of the urban environment. 39 On the contrary, the existing regulations limit themselves to defining different administrative procedures..$^{40}$

It is necessary to add to this analysis the phenomenon of the proliferation of forms of urban illegality under the conditions of exclusion and socio-spatial segregation that have characterized the intense urban growth of Peruvian cities, especially Metropolitan Lima. ${ }^{41}$ This phenomenon takes on greater importance in terms of the socio-economic and cultural processes of access to land and housing production. As a result, an increasing number of people have had to transgress the law to live in cities, occupying slums in peripheral and central areas with inadequate infrastructure and urban services. This has led to a generally precarious, unhealthy, and dangerous housing situation, with no legal security of tenure. 42

\footnotetext{
${ }^{38}$ Gonzales (n 23) 287-290.

39 Gonzales (n 23) 287-290.

40 ibid 311-312.

41 ibid.

42 A Costa and A Hernández, 'Análisis de la Situación Actual de la Regularización Urbana en América Latina: La Cuestión de la Tenencia Segura de los Asentamientos Informales en tres Realidades
} 
Due to these issues, housing should be recognized as a fundamental right and conceived as an indispensable good that enables the enjoyment of other fundamental rights. 43 In this sense, pursuing solutions to improve access to housing in deteriorating urban areas involves reforming the instruments and tools of urban law and urban planning. For example, CEPROMUR considers it necessary to include the notion of the social function of property in the constitutional and urban planning legal system. ${ }^{44}$ This concept is a fundamental key to promoting viable and efficient instruments for the management of land use subject to the common good.

\section{PART 2. CURRENT REGULATIONS FOR THE URBAN RENEWAL IN THE HISTORIC CENTER OF LIMA}

In Peru, a legal framework for urban renewal has been in place since the 1970s. According to the changes that cities have undergone and the differing political views, this has been changed and enacted by different public entities at different levels. ${ }^{45}$ This part indicates the current and valid regulations on which to base the case studies.

First, it is pertinent to note that the limits of the Historic Center of Lima, with its areas of maximum protection and buffer zones, are clearly defined by Municipal Ordinance No. 062 of 1994, issued by the Metropolitan Municipality of Lima. Likewise, interventions

Distintas: Brasil, Colombia y Perú' (2010) 25(68) INVI 121, $123<$ http://dx.doi.org/10.4067/So71883582010000100005>.

43 United Nations, The Right to Adequate Housing (United Nations 2014) 9.

44 CEPROMUR, CEPROMUR y los Procesos de Renovación Urbana, Una reflexión desde la práctica (n 9) 20.

45 CEPROMUR, 'Cartilla Metodológica: Renovación Urbana, Liderazgo Municipal' (n 14) 26. 
on cultural heritage are regulated by the Municipality and the National Building Regulations (Title IV). ${ }^{46}$

According to the Municipalities Organic Law, -Law No. 27972-, urban renewal is a public responsibility, conceived as a power of municipal and provincial governments. As stated in Article 79, ${ }^{47}$ the law defines specific functions exclusive to provincial governments, such as designing and executing urban renewal plans. In addition, it outlines specific shared responsibilities of the district municipalities, such as identifying deteriorated properties and classifying marginal neighborhoods.

At present, Legislative Decree No. 696 of 1991 regulates the general aspects of urban renewal on the national level. Article 1of the decree declares the necessity, public utility, and social interest in promoting private investment in urban renewal actions. ${ }^{48}$ Likewise, Article 3 delimits the levels of responsibility at the different levels of government; Ministry of Housing, Regional Governments, and Provincial Municipalities. ${ }^{49}$ It is pertinent to state that legislation implementing the provisions of this Legislative Decree has been promulgated by Supreme Decree No. 11-MTC promulgated in 1995.

The Metropolitan Municipality of Lima, having exercised its powers, has enacted a series of urban renewal regulations. In this regard, Municipal Ordinance No. 201 of 1998 is considered one of the most comprehensive official documents for the treatment, conservation, and development of the Historic Center of Lima. This ordinance determines

46 UNESCO Centre, 'Historic Centre of Lima' (UNESCO World Heritage Centre) $<$ https://whc.unesco.org/en/list/500> accessed 14 June 2021.

47 Municipalities Organic Law $\mathrm{N}^{\circ} 27972$ 2003, art 79.

${ }^{48}$ Legislative Decree $\mathrm{N}^{\circ} 696$ 1991, art 1.

49 Legislative Decree $\mathrm{N}^{\circ} 696$ 1991, art 3. 
that urban renewal is a shared local urban planning competence that implies that the municipality links heritage protection with urban planning management.50

In addition, in 1999, through Municipal Ordinance No. 237, the municipality created the Metropolitan Fund for Urban Renewal and Development (FOMUR) as a financial instrument for the urban renewal and development of Metropolitan Lima, prioritizing the area corresponding to the Historic Center of the Cercado de Lima district. Its purpose is to promote and participate in the financing of affordable housing programs for the low-income population that include the contribution of private investors. ${ }^{51}$ In accordance with Mayoral Decree No. 128 of 1999, the Board of Directors of Municipal Real Estate Company of Lima (EMILIMA S.A.) was authorized to assume the administration and management functions of FOMUR. $5^{2}$

Subsequently, in 2003, the Metropolitan Municipality of Lima issued Mayoral Decree No. 177, identifying 1325 properties located within the boundaries of the Historic Center of Lima as Microzones for urban renewal treatment. Article 4 of the above-quoted regulation specifies the modes of intervention based on the degree and type of deterioration; remodeling, rehabilitation, reconstruction, and restoration. ${ }^{53}$ Likewise, Article 5 establishes that urban renewal projects will carry out physical and economic actions to achieve, as far as possible, the permanence of the families occupying the renovated property, making the right of residence of the inhabitants prevail.54

\footnotetext{
${ }^{50}$ Municipal Ordinance $\mathrm{N}^{\circ} 201$ 1998, art 54.

${ }^{51}$ Municipal Ordinance $\mathrm{N}^{\circ} 237$ 1999, art 4.

52 Mayoral Decree $\mathrm{N}^{\circ} 1281999$.

53 Mayoral Decree $\mathrm{N}^{\circ} 177$ 2003, art 4.

54 Mayoral Decree $\mathrm{N}^{\circ} 177$ 2003, art 5 .
} 
Likewise, Municipal Ordinance No. 893 of 2005 establishes the zoning of land uses and the index of uses for the location of urban activities in the Historic Center of Lima. This zoning established three treatment zones, in which the land uses are classified according to their functional potential and heritage commitment.55 However, this regulation defined urban and building parameters for each treatment zone, with a very conservative and general vision of the characteristics maintained by each Microzone. It also did not establish a technical mechanism to encourage urban renewal processes with private or mixed (publicprivate) investment.

As a complementary measure, Municipal Ordinance No. 1157 of 2008 establishes the procedure that allows the declaration of uninhabited and the determination of the condition of ruin or slum of the properties located in the Historical Center and the District of Cercado de Lima. In it, it specifies the competent instances and the deadlines in the procedure. ${ }^{6}$ Among its scope, it proposes coercive actions for the immediate eviction of the occupants of the slums for not assuming the difference in cost derived from the rehabilitation actions. 57 The most recent regulation approved for its application at the national level is Law No. 29415 of 2009, which declares of public necessity the process of legal and physical reorganization of slum areas. It grants district and provincial municipalities the power to initiate the urban renewal process..$^{8}$ Among its scope, it stipulates the identification of treatment areas, the declaration of slums, the promotion of the property of organized occupants, the announcement of abandonment/acquisitive prescription, the use of public funds, among

\footnotetext{
55 Municipal Ordinance $\mathrm{N}^{\circ} 893$ 2005, art 2.

${ }_{56}^{6}$ Municipal Ordinance $\mathrm{N}^{\mathrm{o}} 1157$ 2008, art 7.

57 Municipal Ordinance $\mathrm{N}^{\circ} 11572008$, art 12.

$5^{8}$ Law N²9415 2009.
} 
others. In 2010, through Supreme Decree No. 011, the regulation of the provisions established in Law No. 29415 was enacted. This document specifies procedures and conditions applicable to the affected owners, dwellers, and possessors, for that urban renewal, be accomplished through the legal and physical reorganization of slum areas.59

Note that the provisions of Law No. 29415 and Supreme Decree No. 011, prevail over any other regulation that opposes it concerning the law. When this law and its regulations do not provide for a particular matter or in the event of nullity, further legal and customary law provisions which are not incompatible with the law's objective and purpose will be applied. In this sense, Law No. 29415 has not repealed Legislative Decree No. 696, which means that both laws complement each other in matters of urban renewal in the national territory.

\section{PART 3. A SUMMARY OF THREE CASES OF URBAN RENEWAL}

Since the late 1990 s and especially in the 2000s, the Historic Center of Lima has been the scene of urban renewal approaches and projects promoted by the municipal government. According to Ludeña, it has been the historical period that 'has produced the most important contributions in the field of urban design and management, especially in that area in which Peru lacks a consistent design trajectory: urban renewal in central areas. ${ }^{60}$ The case studies addressed were developed in the decade 2000-2010. They are considered referential for representing a wide range of solutions in terms of scale, scope, and implementation

\footnotetext{
59 Supreme Decree N $^{\circ}$ 011-2010-VIVIENDA 2010.

60 Wiley Ludeña, 'Lima: Poder, Centro y Centralidad. Del Centro Nativo al Centro Neoliberal' (2002) 28(83) EURE 45, 60 <http://dx.doi.org/10.4067/So250-71612002008300004>.
} 
mechanisms for urban renewal, as well as for their specific qualities and lessons learned as public policies.

Case 1: The Casa de las Columnas (2009-2010)The building belongs to the Public Charities of Lima and is located two blocks from the Main Square of Lima, in a Monumental Urban Environment. It was declared an Architectural Monument according to Supreme Resolution No. 2900 in $1972 .{ }^{61}$ In 1991 it was included as Cultural Patrimony of Humanity by UNESCO. Later, in 2001, the Metropolitan Municipality of Lima classified it as a Ruinous Building, declaring it a slum and uninhabitable. ${ }^{62}$ In 2002, the National Institute of Culture announced it was an intangible zone in its entirety, including its artistic and architectural elements of heritage value. ${ }^{63}$

In 2007, the World Monuments Fund (WMF) included the Historic Center of Lima in the 2008 Watch List. ${ }^{64}$ As a result, in 2010, the Casa de las Columnas was selected as a pilot project for revitalizing the Historical Center of Lima, part of the measures to ensure the preservation of cultural heritage. In this scenario, the signing of the "Collaboration Agreement" between the Spanish Agency for International Development Cooperation (AECID) and the Ministry of Housing, Construction, and Sanitation in 2008, allowed the

\footnotetext{
${ }^{61}$ Instituto Nacional de Cultura, Relación de Monumentos Históricos del Perú (Instituto Nacional de Cultura 1999) 67.

62 Municipal Opinion $\mathrm{N}^{\circ} \mathrm{O} 382001$.

63 Executive Directorial Resolution N ${ }^{\circ} 161-\mathrm{INC} 2002$.

64 Holly Evarts, 'WMF Announces 2008 Watch List of 100 Most Endangered Sites' (World Monuments Fund, 2009) <https://www.wmf.org/press-release/wmf-announces-2008-watch-list100-most-endangered-sites $>$ accessed 11 July 2021.
} 
initial coordination for the restoration of the Casa de las Columnas. ${ }^{65}$ The WMF and AECID participated in the rehabilitation and enhancement of the Casa de las Columnas as a cooperative agent and it contributed financial support for the project. ${ }^{66}$

Undoubtedly, pressure from civil society played a decisive role in the restoration and enhancement of this building. Since 2004, the board of directors of the building's neighbors asked the Municipality of Lima and the Ministry of Housing for support and technical advice to improve the structures. Through demonstrations and public vigils, the neighbors pressured the authorities to comply with their demands for access to affordable housing in the building they feel is theirs. ${ }^{67}$

Case 2: Housing Complex La Muralla (2003-2008) This project was part of the First Municipal Urban Renewal Program of Block No. 05076 on land owned and possessed by the Metropolitan Municipality of Lima. The block lies within the First Order Monumental Zone of the Historic Center of Lima, which was declared a World Cultural Heritage Site in 1991. The buildings on this block have historical and culturally significance, and many

65 World Monuments Fund, 'Casa De Las Columnas. Social Rehabilitation Through Monument Restoration' in G Palmerio, A Lombardi and P Montuori (eds.), Lima the Historic Center. Analysis and Restoration (Gangemi Editore 2012).

66 World Monuments Fund (n 65).

${ }^{67}$ Silvia De los Rios, 'Centro Histórico "Vivo" de Lima: Inversión y rentabilidad social-financiera para su revitalización', Primer Encuentro Iberoamericano sobre Financiación de la Cultura (Ana Yáñez 2012) <https://ilamdocs.org/documento/3198/> accessed 3 May 2021. 
archaeological finds date back to colonial times. Before the intervention began, the buildings on this block were very precarious, overcrowded, unsanitary, and at risk of collapse. 68

The first step was enacting the Mayoral Decree No. 161 of 2003, which identified the seven buildings that makeup block No. 05076 as Urban Renewal Treatment Microzones. According to the heritage category, three buildings had Monumental Value, two buildings were declared Historical Monument, and two buildings did not have Monumental Value. ${ }^{69}$ During the same year, Council Agreement No. 254 authorized EMILIMA S.A. as the management and execution unit for urban renewal, providing it with political, financial, and regulatory support from the municipal government..$^{\circ}$ In addition, since this was the first experience of the program in marginal neighborhoods in the Historic Center of Lima, the Ministry of Housing and the Mivivienda Fund made several rules governing the housing subsidy program more flexible..$^{71}$ Thus, it was necessary to adapt the qualification system so that families in extreme poverty could access the state subsidy. ${ }^{72}$

As part of its strategy to improve the quality of life of the beneficiaries of the urban renewal project, the municipality launched a social assistance program that included job training and capacity skill-building. The program also offered support workshops and psychosocial counseling. Thus, it enabled the beneficiaries to reintegrate into the labor market and access the credit system.73

68 Wendy Lagos, 'Estrategias para la participación social y productiva en renovación urbana de Centros Históricos' (Unpublished master's thesis, Universidad Nacional de Ingeniería 2021) 160.

69 Mayoral Decree $\mathrm{N}^{\circ} 1612003$.

70 Council Agreement $\mathrm{N}^{\circ} 2542003$.

${ }^{71}$ Municipal Ordinance $\mathrm{N}^{\circ} 8362003$.

${ }^{72}$ Lagos (68) 202.

73 ibid 194. 
Case 3: Pilot Project Martinete (2002-2005) The property owned by the Ministry of Transportation, Communications, Housing, and Construction, known as Martinete backyard, is located between the banks of the Rimac River and the Huerta Perdida human settlement in Barrios Altos. Before the intervention, it was in a state of abandonment because it was located in an urban fringe area and had long been a clearing and landfill site in Lima. There was a degraded urban environment, unhealthy riverbanks, high levels of insecurity, and a precarious housing situation. ${ }^{74}$

The Pilot Project Martinete was part of the "Housing Pilot Projects Program" created in 2002 by Supreme Decree No 019, under the "National Housing Plan for All." Through this program, private investment would be encouraged in the real estate sector to revitalize deteriorated or underused areas of the country's cities. 75 The execution of this project included integrated actions between the Vice-Ministry of Housing and Construction and the Special Commission for Advice and Development of Strategic Projects of the Metropolitan Municipality of Lima. ${ }^{76}$ As part of the Work Contract with the Vice-Ministry of Housing and Construction, the National University of Engineering was responsible for executing the housing project dossier.

The primary purpose of this project was to create a new real estate product that would target classes $\mathrm{D}$ and $\mathrm{E}$ in the surrounding neighborhoods of Martinete. $77 \mathrm{~A}$ second objective was to introduce new technical procedures into the urban planning regulations to

74 Luis Cabello, 'Pilot Project for C and D Socio-economic Sectors' (2009) 2(1) CA 53 <http://cybertesis.uni.edu.pe/handle/uni/15070> accessed 23 March 2021.

75 Supreme Decree $\mathrm{N}^{\circ}$ 019-2002-MTC 2002.

${ }^{76}$ Supreme Decree No $043-2001-\mathrm{MTC} 2001$.

77 Supreme Resolution $\mathrm{N}^{\circ} \mathrm{OO2}-2003-\mathrm{MVC} 2003$. 
enhance the habilitation and building procedures. ${ }^{78}$ Despite this, the project, which was supposed to provide affordable housing for the Martinete neighborhood's residents, ended up being awarded to an outside party. In this case, the non-local applicants qualified for a loan and received public subsidies for housing as they did meet the required financial criteria. 79

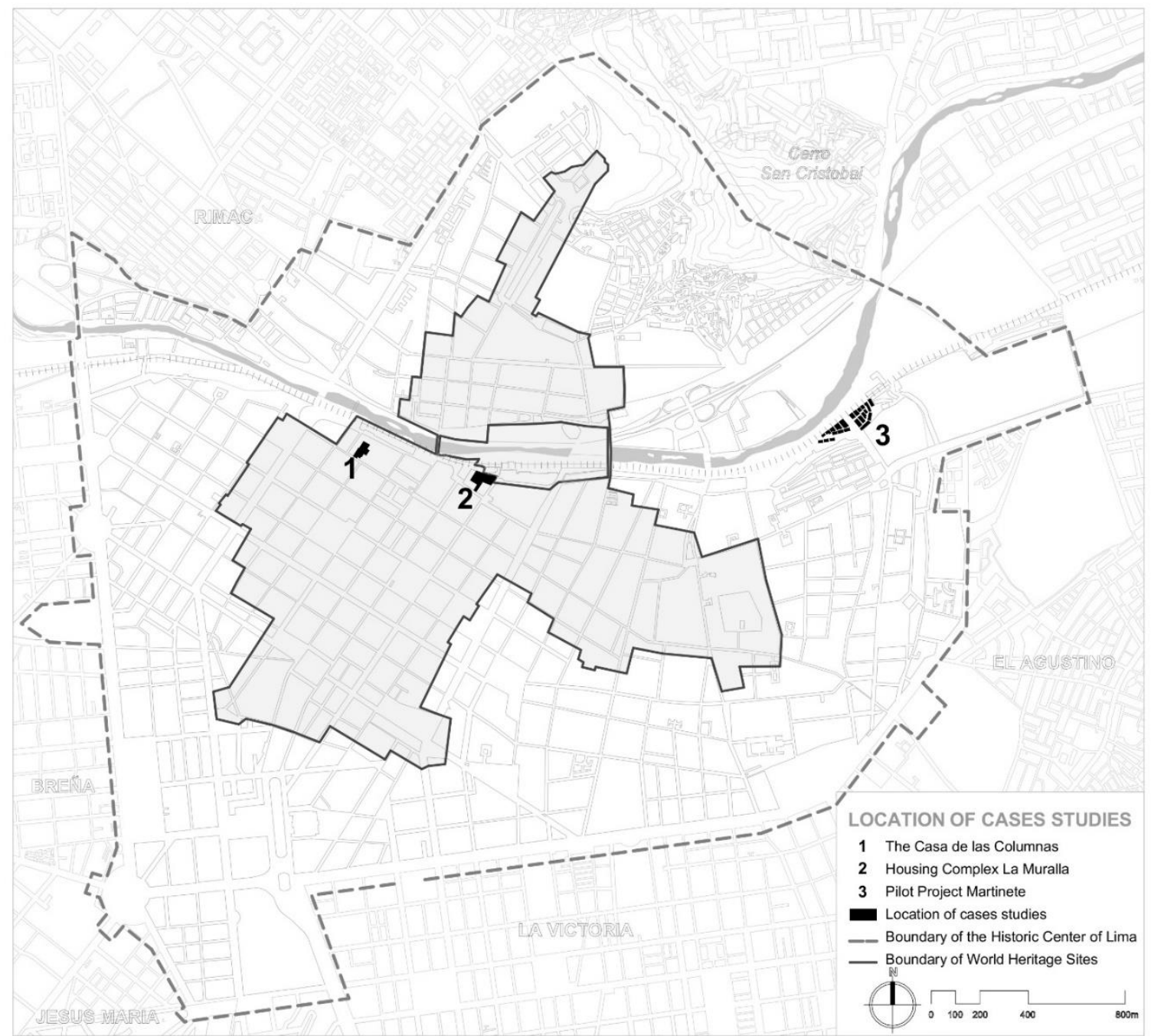

Figure 1. Location of cases studies (source: Author).

${ }^{78}$ Silvia De los Rios, 'Acciones de Renovación Urbana para hacer de Lima un Centro Vivo' (CIDAP 2008) 4 .

79 ibid. 


\section{PART 4. DISCUSSION}

In the case of the Casa de las Columnas, it is relevant to highlight the participation of civil society as promoters of the urban renewal process. In recognition of the cultural heritage value of the building, grants for its restoration were forthcoming from international agencies (such as AECID and WMF). It made it possible to carry out studies and initiate strategic actions for the restoration of the building. However, at present, the process is still pending, awaiting a set of public policies that will allow the comprehensive renewal of the building and, at the same time, guarantee the right to affordable housing for the residents through the sale or transfer of the state-owned property.

As for the second case, the Housing Complex La Muralla was an experience that contemplated a comprehensive and participatory management approach with the beneficiaries. The project succeeded in creating a sense of community and identity by implementing social participation and productivity strategies. Also, it is pertinent to highlight the municipal political decision in the execution of the urban renewal program, which led to enacting a specific regulatory framework to provide the metropolitan municipality with legal powers and financial support for urban renewal. However, the fact that FOMUR was exclusively available for municipally-owned projects leads to controversy since the initiative of private owners with limited access to funds was restricted. Because of the latter, this experience does not apply to other contexts. ${ }^{80}$

Concerning the Pilot Project Martinete, one of the most noteworthy aspects was the goal of presenting new technical procedures for habilitation and construction stages of urban

\footnotetext{
80 CEPROMUR, 'Cartilla Metodológica: Renovación Urbana, Liderazgo Municipal' (n 14) 13.
} 
renewal. Such regulations would then be incorporated into the urban planning regulations, but to date, none of these technical processes have an official regulatory status. Therefore, the original construction has undergone significant modifications, such as additions or new construction, without technical oversight or assistance. This project has also drawn criticism for not meeting the housing demand of the surrounding degraded neighborhoods. The reason is that in the housing allocation process, the beneficiaries were people from outside the area. In addition, no consideration was given to the development of socio-economic promotion programs for the surrounding inhabitants in vulnerable conditions.

It is important to note that the current situation presents, to some extent, greater scope in the promotion of housing policies compared to the 1990s. As a consequence of the country's institutional weakness, the state apparatus was dispersed and disconnected from local governments. In practice, this allowed the administration of the day to excuse itself from the omission of governmental functions. The result was an overlapping of regulations and competencies that affected citizens, investors, and, above all, cities. Yet, this set of laws remains partially implemented, regulating the country's development. In this context, there do not seem to be effective mechanisms to reach political agreements on the recovery of traditional centers that address the different dimensions -physical, legal, economic, social, political- of the urban renewal process. ${ }^{81}$

Based on the cases presented, it is evident that the solution to the housing problem in urban renewal treatment areas requires a legal and management structure that defines general guidelines and, in turn, allows for specific adaptations throughout the process.

${ }^{81}$ CEPROMUR, 'Cartilla Metodológica: Renovación Urbana, Liderazgo Municipal' (n 14) 12-22. 
Housing policies must be created within a management environment that lends itself preferentially to the interests and needs of vulnerable social sectors residing in deteriorated traditional neighborhoods. In this sense, urban renewal plans should incorporate existing housing patterns, the characteristics of their inhabitants, and the living heritage and cultural values inherent to historic areas. ${ }^{82}$

The requirement for maintaining long-term commitments, a necessary condition for urban renewal projects to mature, adds another layer of complexity to the problem. Thus, management mechanisms and operational and political instruments must support the development of new forms of management of urban interventions that lead stakeholders to agree on long-term objectives. ${ }^{83}$ In this sense, although urban projects fall within specific zoning and building ordinances approved by the municipal government, administrative actions that seek to give stability and credibility to the project should not generate inflexibilities that prevent and limit its future adaptation to other circumstances. ${ }^{84}$ In other words, the flexibility of the urban project depends on the management structure, which, in turn, is subject to institutional decisions and the capacity to absorb changes in the city. Therefore, the urban project and the management structure are interdependent and must be carefully defined at the beginning of the urban renewal process. ${ }^{85}$

From the literature and case studies examined in this study, it is possible to formulate recommendations for a policy and legal framework for urban renewal in collective housing. First, it is necessary to replace traditional urban planning instruments with others

\footnotetext{
82 Gamini Wijesuriya, 'Living Heritage: A summary' (ICCROM 2015).

83 Rojas (n 11) 22-23.

84 ibid 24-25.

85 Rojas (n 11) 24-25.
} 
that promote and guarantee the completion of consensual long-term goals, stipulated in a phased development and intervention plan. Given the urgency of realities such as the Historic Center of Lima, it is imperative to address poverty and habitat precariousness. For this reason, the comprehensive plan should establish progressive urban rehabilitation programs, property regularization, and technical assistance to expand and improve existing housing. In this sense, the legal recognition of the right to affordable housing for residents of deteriorated urban areas should constitute a matter of public interest.

In terms of land regulation in urban renewal, urban planning regulations should include fiscal instruments to control urban speculation. To this end, government incentives should promote real estate investment without granting tax exemptions or other types of concessions beyond what is strictly necessary. Along the same lines, it is critically important to establish transparent and efficient contracting procedures and to develop adequate contracting models that allow for continuous control and supervision throughout the process. On the other hand, as a social support strategy, the programs must establish financial support mechanisms taking into account the economic limitations of the residents. Therefore, it is crucial to integrate socioeconomic development tools at the local level. And finally, for the recovery process to be successful, it should be incorporate tools for effective citizen participation and create platforms for coordination and cooperation among the different groups involved in the urban renewal process. 
Study limitations \& future work The present research partially fills the information and analysis gap that exists on the legal framework of urban renewal and housing policies in deteriorated central areas of Peru. Indeed, being an exploratory, descriptive and analytical investigation of urban renewal experiences in the city of Lima in the decade 2000-2010, it has several limitations that merit further studies in the future. To begin with, it does not include a post-implementation analysis, nor does it evaluate the success of the intervention. In addition, it does not address in-depth aspects of the current conditions of the projects, anticipating that other research can address it to have a comprehensive and temporal perspective of urban renewal policies.

\section{CONCLUSIONS}

Based on the legal analysis of the direct and indirect effects of the regulatory-administrative set on the urban transformation of deteriorated central areas, it confirms that urban renewal is an urban planning competence shared by the State as a whole. Urban renewal implies the continuous exercise of competencies and actions by public entities through normative and operational devices, which direct the recovery process. However, the success of the urban renewal process depends on the consensus and joint decision of all parties involved. In summary, the legal basis is a crucial precondition for implementing urban renewal policies, but it is insufficient without political leadership, public institutionalism, and citizen participation.

It is also important to note that since traditional neighborhoods represent a physical structure with historical significance and cultural heritage value, they deserve a more indepth approach. Public policy discourse cannot focus solely on technical arguments about 
the material restoration of the neighborhood's historical character; instead, it should place the residents - the living heritage - at the center of it. As Poulios explains, the "living heritage" approach, rather than emphasizing the preservation of the urban fabric, emphasizes the intangible connection of the community to the historic neighborhood. ${ }^{86}$ For this reason, the urban renewal legal framework must ensure the active participation of citizens before, during, and after the intervention. Social cohesion, therefore, plays a crucial role in recognizing the collective efforts and everyday actions of residents in the urban renewal process.

In summary, the three urban renewal projects exemplify the current confusing legal environment in Peru. Each of them was carried out by a different government entity under a distinct legal norm, despite being within the same geographical area and covering the same period. The above examples demonstrate the wide dispersion and overlapping of legal frameworks associated with land management and governance in Peru. Consequently, the recovery of deteriorated urban areas remains a pending task, which requires the implementation of policies and legislation sensitive to the urgent needs of the inhabitants. Thus, it implies a greater emphasis on integrating and situating the housing issue in broader legal, cultural, psychological, social, and economic contexts, reflecting the characteristics and complexities of the inhabited territory. The result should lead to a legal and institutional framework that ensures replication and the management and sustained execution of public policies of urban renewal for collective housing.

86 Ioannis Poulios, 'Discussing Strategy in Heritage Conservation' (2014) 4 JCHMSD 16. 
This research concludes that urban renewal should proceed with more commitment and determination within a national housing policy that guarantees the right to affordable housing. In this sense, the norms that regulate urban development in Peru must evolve into a normative body based on the principle of the social function of property, land rights, and social welfare. ${ }^{87}$ This would facilitate the construction, conservation, and renewal of cities that allow people to live in dignity, acknowledge their rights as citizens, and provide them with a fair distribution of resources, facilities, and services.

\section{ACKNOWLEDGMENTS}

I wish to extend my gratitude to Luz Estremadoyro, director of the Centro de Promoción Urbana (CEPROMUR), for providing me with research materials, which I rely on in conducting this study. To Willey Ludeña whose teaching encouraged my interest in other disciplines related to urbanism and stimulated the creation of the present study that aims to contribute to the understanding of the lack of access to affordable housing and quality habitat for the inhabitants of deteriorated urban areas.

87 Gonzales (n 23) 88. 